\title{
REKONSTITUCE TRAGICKÉ ZKUŠENOSTI VE FOUCAULTOVÝCH DËJINÁCH ŠÍLENSTVÍ
}

\section{Miloš Kriššák}

Předkládaná studie je interpretací díla Michela Foucaulta Š́lenství a nerozum: Dějiny šilenství v klasickém věku. Rozlišuje několik syžetových plánů knihy a snaží se navrátit $\mathrm{k}$ původním intencím jednoho z nich: k ,archeologii nerozumu“. Cílem studie je ukázat, že smyslem „archeologie nerozumu“ je rekonstituovat tragickou zkušenost a aktualizovat ji jako otázku, zdali je dnes vůbec možné být tragickým, aniž by taková exprese byla nutně označena za šílenství. Abychom tuto otázku prokázali jako jednu z intencí Foucaultovy knihy, je nutné vrátit se ke sporu o „archeologii mlčení“" a ukázat, že to, co má být touto archeologií vysloveno, není šílenství samo, jak zní námitka kritiků, nýbrž šalba rozumu, který překrývá svou historii a mlčí o svém původu ve vztahu k nerozumu. Popis Foucaultova archeologického postupu odhaluje spjatost jeho metody s Nietzscheovým genealogickým projektem přehodnocení všech hodnot. Abychom vyjasnili souvislost mezi příběhem nerozumu a tragickou zkušeností, předvádíme v následující části vztah rozum - nerozum jako paralelu k Nietzscheovu pojetí apollinského a dionýského, čímž se tato spjatost ještě prohlubuje. Z tohoto nietzscheovského podloží poté povstává otázka tragična, jíž se ve Foucaultově knize dostává tak svérázného uvedení.

\section{1. „Archeologie nerozumu“ jako projekt}

Foucaultovy Dějiny šilenství (1961) dlouho ve skutečnosti zůstávaly málo známou knihou. Ze dvou důvodů: všechny překlady (s výjimkou italského) vycházely po dlouhou dobu ze značně zkráceného paperbackového vydání díla z roku 1964, jež se navíc stalo předmětem diskuse či kritiky ve světle Foucaultových pozdějších konceptů. Abychom se vyhnuli konfúzím, které tyto skutečnosti způsobily, volíme za základní metodologickou prioritu „návrat k dílu samému“. Nechceme hledat anticipace Foucaultových pozdějších teorií, ani nabízet sumarizující pohled na Foucaultovo dílo. Chceme poukázat na jeden zásadní aspekt Dějin 
šilenství, který zůstal poněkud v pozadí, zastíněn novými Foucaultovými idejemi a novými interpretacemi, a to v tom smyslu a rozsahu, v jakém nám ho dílo samo nabízí. ${ }^{1}$

Dějiny šilenství z roku 1961 obsahují hned několik syžetových rovin: 1. „Archeologii šílenstvi““ jako rekonstituci těch forem zkušeností, které určily povahu západního rozumu; 2. „dějiny šílenstvi““ jako hledání podmínek možnosti konstituování psychologie či psychiatrie jako vědy; ${ }^{2}$ 3. „dějiny šílenství“ jako hledání podmínek zrodu historie; ${ }^{3}$ a konečně 4. ,archeologii nerozumu“ jako rekonstituci tragické zkušenosti. Ačkoli

1 Toto dílo M. Foucaulta původně vyšlo pod názvem Folie et Déraison. Histoire de la folie à l'âge classique (Paris 1961) ve vydavatelství Plon. Ve druhém vydání z roku 1972 (u Gallimarda) odstranil Foucault z názvu Š́lenství a nerozum (Folie et Déraison), změnil úvod a zařadil dva dodatky. Následující, o čtyři roky mladší dotisk obsahuje vydání z roku 1972, avšak už bez dodatků; srv. M. Foucault, Histoire de la folie à l'âge classique, Paris 1976 (= HF). Právě toto vydání zde užíváme. Předmluvu k prvnímu vydání a dodatky ke druhému vydání citujeme podle M. Foucault, Dits et écrits I. 1954-1975, Paris 2001 (=DE I). Přihlížíme též k českému překladu, který vychází z podstatně zkráceného vydání z roku 1964; srv. M. Foucault, Dějiny šilenství, přel. V. Dvořáková, Praha 1994. O to, že v centru pozornosti stála především zkrácená verze, se zasloužila i okolnost, že anglické vydání z roku 1965 (pod názvem Madness and Civilization) vycházelo právě ze zkrácené francouzské verze. Širší recepce původní, nezkrácené podoby díla začíná až v devadesátých letech 20. století. V roce 1990 publikuje Colin Gordon článek, ve kterém upozornil na rozpor mezi oběma verzemi knihy; viz C. Gordon, Histoire de la folie: an Unknown Book by Michel Foucault, in: History of the Human Sciences, 3, 1990, str. 3-26. C. Gordon dokládá rozdíly v recepci Foucaultova díla ve francouzském a anglicky mluvícím prostředí, dané čtením rozdílných verzí knihy. Vzrůstající zájem o původní dílo zavdal podnět k novému anglickému překladu kompletní verze, který vznikl v roce 2006; viz M. Foucault, History of Madness, London - New York 2006. Foucaultovo první velké dílo však nepřestává být předmětem zarputilého interpretačního zápasu, jak ukazuje C. Gordon i ve své stati pro Blackwell Companions z roku 2013; srv. C. Gordon, History of Madness, in: Ch. Falzon - Th. O'Leary - J. Sawicki (vyd.), A Companion to Foucault, Oxford 2013, str. 85. Ke zdrojům, které tyto diskuse mapují, viz pozn. 32.

2 Srv. M. Foucault, Préface, in: DE I, str. 192-194: „Strukturální studium [šílenství] se musí navrátit k rozdělení, které rozum a šílenství jak propojuje, tak odděluje; musí se pokusit odkrýt neustálou výměnu, společný temný kořen, původní setkání, jež uděluje smysl jednotě a též opozici smyslu a nesmyslného ... V centru tohoto pokusu stojí navrácení hodnoty klasické zkušenosti šílenství v jejím právu i v jejím osudu ... V rekonstituci zkušenosti šílenství se píše sama historie podmínek možnosti psychologie.“"

3 Srv. tamt., str. 191: „Dějiny jsou možné pouze na pozadí absence historie, v prostředí tohoto velkého prostoru šelestění ... Potřeba šilenství v průběhu celých dějin Okcidentu je propojená v tomto rozhodujícím gestu, vydělujícím smysluplný jazyk od šumu pozadí a jeho přetrvávající monotónnosti, jazyk, jenž se přenáší 
se tyto roviny přestupují a vzájemně předpokládají, soustředíme se v této studii především na objasnění poslední z nich. V první části studie poukážeme na Foucaultem ohlášený záměr „archeologie nerozumu“ a na možné důvody jeho pozdějšího vypuštění klíčových pasáží z prvního vydání. Abychom mohli sledovat původní záměr Foucaultova textu, bude třeba se vrátit právě k opuštěným částem jeho díla.

Smysl svého zkoumání objasňuje Foucault v předmluvě z roku 1961:

„Je třeba vrátit se dějinami šílenství k nulovému bodu, kdy bylo šílenství nediferencovanou zkušeností, stále nerozdělenou zkušeností rozdělení samého. ... Konstituování šílenství na konci 18. století, svědčící o ruptuře v dialogu, nám podává oddělení jako vždy již ustavené a vypuzuje z paměti všechna ta nedokonalá slova nepevné syntaxe, vyslovená koktavě, slova, kterými se realizovala výměna mezi šílenstvím a rozumem. Jazyk psychiatrie, který je monologem rozumu $o$ šílenství, mohl vzniknout pouze v tomto mlčení.

Mým záměrem nebylo psát historii jazyka psychiatrie, ale spíše archeologii onoho mlčení."4

Foucaultovo ohlášení „,archeologie mlčeni' si vyžádalo svou daň. Je těžké si představit, že výraz ,archeologie mlčení“ označuje nějakou metodu ve vlastním smyslu. Je to spíš rétorický obrat, který má, jak se ukáže, problematickou výpovědní hodnotu. Je symptomatické, že celou starší předmluvu Foucault v novém vydání knihy z roku 1972 vyškrtl a nahradil mnohem kratším uvedením, $\mathrm{v}$ němž $\mathrm{v}$ podstatě odmítá převzít jako autor odpovědnost za vykládání toho, co rríká samo dílo (nebo - abychom nebyli nespravedliví: odmítá vzbuzovat ve čtenáři jakoukoli intenci, s níž by měl knihu číst). Dílo již žije svým životem, svými zdvojeními, a autorovo právo na výklad textu není jiné než právo kteréhokoli jiného čtenářre. ${ }^{5}$

a završuje v čase; jedním slovem, potřeba šílenství je propojená s možností historie."

4 Tamt., str. $187-188$.

5 Srv. M. Foucault, $H F$, str. 9-10: „Pro toho, kdo napsal knihu, je velikým pokušením převzít kontrolu nad všemi záblesky simulaker, nadiktovat jim formu, opatřit je identitou, vnutit jim otisk, který jim všem dá nějakou konstantní hodnotu ... Přál bych si, aby kniha, přinejmenším pro toho, kdo ji napsal, nebyla ničím jiným než větami, ze kterých je poskládána." Tato nová předmluva je jasnou ozvěnou Foucaultových myšlenek, které později nacházíme přesněji načrtnuté v jeho 
Foucault však měl dva dobré důvody, proč chtěl nebo musel svoji původní předmluvu odstranit. Prvním důvodem mohla být Derridova ostrá kritika, ${ }^{6}$ která kromě známé polemiky kolem interpretace Descarta vyzdvihovala problematičnost „archeologie mlčeni“ jakožto nemožné pozice, neuskutečnitelného projektu, poněvadž nikdy není možné vyslovit „,šílenství samo“. ${ }^{7}$ Sám tento důvod však nepostačuje. Do nového vydání zařadil Foucault dva dodatky: Š́lenství, absence díla a Moje tělo, tento papír, tento oheň, jež byly neméně ostrou obranou vůči Derridovi. ${ }^{8}$ Pokud tedy Foucault ubránil svou pozici, proč by odstraňoval text, který byl, alespoň zčásti, předmětem sporu? Musel k tomu přispět i jiný důvod: Foucault si uvědomil, že uvedení jeho práce jako ,archeologie mlčení“ nevyznívá št’astně, avšak nikoli z důvodů, které kritizoval Derrida, ale spíš pro myšlenku archeologie, jak se postupně vyvinula $\mathrm{v}$ jeho následujících pracích. Archeologie vědění z roku 1969 fixovala archeologii jako analýzu ,skutečných výpovědí (at' už vyslovených nebo napsaných)“, tj. jako ,projekt popisu diskursivních událostí'“. 9 To je samozřejmě v př́krém rozporu s předpokladem, že by archeologie mohla být historií mlčení nebo snahou rekonstruovat nějakou zkušenost. ${ }^{10}$

přednášce z roku 1969 Co je autor?, viz M. Foucault, Co je autor?, in: Diskurs, autor, genealogie, přel. P. Horák, Praha 1994, str. 41-62.

6 Derrida svou přednášku z roku 1963, se kterou vystoupil proti Foucaultovi, zařadil do knihy L'écriture et la différence, Paris 1967. Český překlad: J. Derrida, Cogito a dějiny šilenství, in: Násilí a metafyzika, přel. J. Pechar, Praha 2002, str. $185-234$.

7 Srv. tamt., str. 193: „Bud'to mlčet určitým mlčením ..., anebo sledovat šílence na cestě jeho exilu. Neštěstím šílenců, nekonečným neštěstím jejich mlčení je to, že jejich nejlepšími mluvčími jsou ti, kdo je nejlépe zrazují; je jím to, že když někdo chce ř́íci jejich mlčení samo, přešel už k nepř́iteli a na stranu řádu..." - K této problematice viz též M. Marcelli, Derrida a Foucault: jedna marginálna polemika, in: M. Sedláčková (vyd.), Vliv díla Jacquesa Derridy na současné myšlení, Praha 2007, str. 87-96.

8 Srv. M. Foucault, La folie, l'absence d'œeuvre, in: DE I, str. 440-448; a týž, Mon corps, ce papier, ce feu, in: DE I, str. 1113-1136. Druhý článek Moje tělo, tento papir, tento oheň z velké části opakuje myšlenky, které Foucault uveřejnil již počátkem roku 1972 během svého pobytu v Japonsku v (japonském) časopise Paideia s jednoduchým názvem Odpověd' Derridovi; srv. M. Foucault, Réponse à Derrida, in: DE I, str. 1149-1163.

9 Srv. M. Foucault, Archeologie vědění, přel. Č. Pelikán, Praha 2002, str. 44.

10 Foucault v Archeologii vědění tvrdí (tamt., str. 76), že ,záměrem [archeologie] není rekonstruovat, čím mohlo být šílenství o sobě, takové, jaké by se zprvu nabízelo v nějaké primitivní, základní, neurčité, sotva artikulované zkušenosti“, a k tomu v pozn. 1 pod čarou doplňuje: „To je v př́imém rozporu s tématem expli- 
Proto zde vycházíme z úvahy, že Foucault vypustil původní předmluvu právě proto, že pozici archeologie sám redefinoval. Tím spíš platí, že pokud se chceme vrátit k původním intencím Dějin šilenství, musíme pozdější redefinice odsunout stranou a navrátit „archeologii nerozumu“ její původní smysl.

\section{Smysl „archeologie mlčení“}

Důležitým faktem, který můžeme $\mathrm{z}$ výše citované pasáže $\mathrm{z}$ předmluvy vyčíst, je cíl nebo vodící linie, kterou Foucault ohlašuje: totiž vrátit se dějinami šílenství až $\mathrm{k}$,nulovému bodu, kdy bylo šílenství nediferencovanou zkušeností“. Tato formulace vyjadřuje hned dva důležité aspekty: Za prvé, že existuje nějaký „nulový bod“, a za druhé, že v archeologickém projektu jde o rekonstituci jisté zkušenosti. ${ }^{11}$

Pro objasnění pojmu „,nulového bodu“ zapojuje Foucault do své brilantní rétoriky celý arzenál termínů a implicitních tezí, které mají podobu jakési dialektizované kvazifenomenologie. Podle Foucaulta existuje něco jako originární disociace původní jednoty řeckého logu, která jako jeden z rozhodujících faktorů - určila podobu toho, co nazýváme „západní svět“. Uvnitř logu vznikla trhlina, která odděluje rozumné od něčeho, co má být odlišné (nerozum), a vede s tímto Jiným živý rozhovor. Látkou Foucaultova historického př́iběhu je nové oddělení, které počíná 17. stoletím a které vyloučilo nerozum zevnitř rozumu a odmítlo ho jako to, co nemá žádný logos (rozumnou řeč). Tato událost je v dějinách šílenství následně vystupňována: To, co bylo odsunuto do bezhlesé existence v polostínu uvěznění a vyloučení, je přivedeno zpátky do světla, leč pod pohled vědeckého názoru. A tak se v pozitivistickém věku konstituuje šílenství jako „duševní nemoc“, o níž psychiatrie (jako věda o tomto předmětu) vede vylučující monolog.

Vrátit se k „nulovému bodu“ tak znamená psát historii hranice, oddělení, psát historii

citně uvedeným a několikrát opakovaně přítomným v Dějinách šilenství, zejména v předmluvě.“ Jako by se zde Foucault chytal do pasti svých vlastních kritiků. Byt' se Foucault snaží evokovat jistou základní zkušenost, nikde v Dějinách šílenství není explicitně formulován záměr vyslovit „šílenství samo“. K tomuto tématu viz dále pozn. 33 .

11 „Rekonstituce zkušenosti“ je Foucaultovo vlastní spojení; srv. pozn. 2. 
„těch obskurních gest, nutně zapomenutých, jen co se naplnila, jejichž prostřednictvím zapovídá kultura něco, co pro ni bude Vnějšskem“. 12

Zde dostává smysl ,archeologie mlčení a jejím prostřednictvím i vlastní povaha archeologického zkoumání. Gesta oddělení jsou zapomenuta. Hlasu šílenství se nedostává sluchu. Cílem plánu historie, která si chce říkat archeologická, je znovu vydobýt to, co bylo vypuzeno z paměti vytěsněná pudenda origo (nečistý původ). ${ }^{13}$ Freudovská metafora tady dostává jasně nietzscheovský nádech. To je genealogický plán ,archeologie šílenství“. Neutrálnost archeologického jazyka, kterou Foucault požaduje, znamená neutrálnost ve vztahu ke kognitivním a morálním preskripcím, nikoli neutrálnost ve smyslu vědecké nezainteresovanosti, spíše se pracuje s vědomím ,př́liš lidské vědy“. ${ }^{14}$ Foucault věnuje velkou pozornost i otázce morálního odsouzení šílence, tedy konstituování hodnoty šílenství, která se spolupodílela na proměně šílenství v objekt vědeckého poznání. Proklamovaná neutrálnost tedy spočívá právě v kritickém odstupu - řečeno spolu s Nietzschem:

„kritika morálních hodnot, [kde] musí být ted’ prozkoumána hodnota těchto hodnot samých - a k tomu je nutno znát podmínky a okolnosti, z nichž tyto hodnoty vyrostly, za nichž se vyvíjely a posouvaly (mo-

12 M. Foucault, Préface, in: DE I, str. 189.

13 V Dějinách šílenství nazývá Foucault příležitostně tyto skryté události „systémem podzemních operací“ (un système d'opérations souterraines), srv. M. Foucault, $H F$, str. 120. Ve svém pozdějším textu z roku 1971 mluví Foucault sám o smíchu nad slávou původu, kterému nás učí historie neboli nietzscheovská genealogie; srv. M. Foucault, Nietzsche, genealogie, historie, in: Diskurs, autor, genealogie, str. $76 \mathrm{n}$.

14 Srv. M. Foucault, Préface, in: DE I, str. 187: „Musíme odmítnout komfort konečných pravd, nesmíme se nikdy nechat vést tím, co snad již o šílenství víme. Žádnému pojmu psychopatologie, a především ani implicitní hře retrospektivy, není možné dovolit, aby hrála organizující roli.“ A dále na str. 194: „,Cílem bylo] umožnit slovům a textům [dokumentů], které přicházejí zpod povrchu jazyka, a které nevznikly, aby tento jazyk dosáhly, aby promlouvaly samy o sobě, aniž bychom se odvolávali na jakékoli psychiatrické ,pravdy‘. Snad nejdůležitější součástí této práce je podle mě to, že jsem ponechal prostor archivním textům samým." Foucault na konci své předmluvy popisuje v gestu hodném heideggerovského obrazu, který odkrývá a zakrývá zároveň, svoji „metodu“, tamt., str. 194-195: „V postupech a metodách jsem se přidržoval pouze toho, co je shrnuto v Charově textu .... ,Odstranil jsem z věcí iluzi, již vytvářejí, aby se před námi ochránily, a ponechal jsem jim jenom tu část, kterou se nám doznávají.““ 
rálka jako důsledek, jako symptom, jako maska, jako pokrytectví, jako nemoc, jako nedorozumění; ale též morálka jako př́íčina, jako lék, jako povzbuzení, jako zábrana, jako jed) ..."15

„Archeologii“ tedy musíme porozumět taktéž jako tomu, co zbavuje diskurs morální vázanosti; pozicí archeologie je pozice „mimo dobro a zlo“. Pokud uznáme, že „,archeologie mlčení“ je vskutku projektem přehodnoceni všech hodnot, uvědomíme si zároveň, v čem tkví hluboké nedorozumění kritiků: Metoda archeologie nespočívá v tom, že nechává promlouvat šílenství jako takové, nýbrž v tom, že nechává promlouvat dokumenty, archivní texty, aby je $\mathrm{v}$ jejich řeči přistihla opakovat gesto, které bylo dávno vypuzeno z paměti, tj. postupnou proliferaci odvrhování z „nulového bodu“ původně „,nediferencované zkušenosti oddělení“.

Smyslem ,archeologie mlčení není tedy přivést k řeči mlčenlivého šílence; „mlčení“ tu neoznačuje šílenství. „Mlčení“ se vztahuje k rozumu. To rozum mlčí o svém vlastním původu. To rozum překrývá a zamlžuje a nechce vyslovit, že to, co odvrhuje jako svůj naprostý opak (šílenství), je fenomén, s nímž jakožto s nerozumem vedl kdysi dialog a v jednotě s nímž byl kdysi zrozen. Archeologie mlčení přistihuje rozum u jeho lži. Nevyslovuje ,šílenství samo“. Tímto odhalením demaskuje též pochybnou hodnotu objektivity, za kterou se vědění o šílenství rádo skrývá. „Archeologie“ je Foucaultovo krytí pro historiografickou genealogii pod znamením Nietzscheho. ${ }^{16}$

15 F. Nietzsche, Genealogie morálky, přel. V. Koubová, Praha 2002, str. 12. Jednou bude třeba číst Dějiny šílenství jako ,genealogii morálky“. Sám Foucault v HF, na str. 101, píše: „Téma vztahu mezi medicínou a morálkou je bezpochyby tak staré jako řecké lékařství. Ale od 17. století a pořádku křest’anského rozumu bylo institucionalizované ve formě, která u Řeků neměla obdobu: ve formě represe, útlaku, povinnosti vykoupení.“ A o několik stran později (na str. 106) píše znova: „Je pravda, že naše vědecké a medicínské poznání šílenství spočívá implicitně na předcházejícím konstituování etické zkušenosti nerozumu.“

16 Georges Canguilhem nazývá Dějiny šilenství zkoumáním ,genealogickým“ a poukazuje na to, že zde Foucault nastoluje otázku normy a normalizace, moci a represivního aparátu, kterou teprve rozvine v práci Dohližzet a trestat; srv. G. Canguilhem, Sur l'Histoire de la folie en tant qu'événement, in: Le Débat, 41, 1986, str. $37-40$. 


\section{Pod znamením Nietzscheho}

Odstraněním originálního názvu Folie et Déraison, tedy i duality „„šílenství“ a „nerozumu“, a stejně tak i krácením vydání z roku 1964, jež soustřed'ovalo pozornost na příběh šílenství, došlo $\mathrm{k}$ překrytí jedné z vlastních, původních intencí díla, kterou Foucault původně ohlašoval značně emfaticky:

„V srdci těchto hraničních zkušeností západního světa je zajisté exploze tragična samého. Jak ukázal Nietzsche, tragická struktura, ze které se utvořily dějiny západního světa, není ničím jiným než odmítnutím, zapomenutím a tichým úpadkem tragédie. K této zkušenosti, která je klíčová, jelikož svazuje tragické s dialektikou dějin v samém odmítnutí tragédie historií, gravitují mnohé další zkušenosti...

Následující studie bude jen prvou a bezpochyby nejjednodušší z těch, které by chtěly v dlouhém sledu výzkumů - pod sluncem velkého nietzscheovského hledání - konfrontovat dialektiku historie s nehybnou strukturou tragična."17

K archeologickým dějinám šílenství jakožto dějinám mlčení rozumu o jeho původu a umlčení šílenství ve vědeckém monologu neoddělitelně patří snaha evokovat tragično samo, navracející se s hlasem nerozumu, který Foucault neustále připomíná prostřednictvím děl Bosche, Goyi, de Sadea, de Nervala a jiných, ale především - ve vztahu k dnešku - hlasem Artauda a Nietzscheho.

Nietzscheovské světlo, které zkoumání vede, zjevně souvisí s tím, co nacházíme v Nietzscheho spise Zrození tragédie. ${ }^{18}$ Foucaultovo vyhlášení o studiu „pod znamením Nietzscheho“ není vůbec triviální či pouze metaforické. Je analogické: Klíčovou črtou Nietzscheho popisu konce tragického člověka je předvedení - abychom parafrázovali Foucaultova slova - originární disociace jednoty tragického světa, která se stala určující pro povahu Okcidentu jako světa vědeckého optimismu. Původní jednota sváru apollinského a dionýského, která člověku umožňovala jednotu s ,nejvnitřnějším základem světa“a a zakládala tragické myšlení, jež dostojí „metafyzickému významu života“, 19 je rozbitá s př́íchodem (sókratovské) rozumující dialektiky. Př́ičinou zániku řecké tragédie je

17 M. Foucault, Préface, in: DE I, str. 189 n., zvýraznil M. K.

18 F. Nietzsche, Zrození tragédie, přel. O. Fischer, Praha 2014.

19 Srv. tamt., str. 35 a 199. 
odtrhnutí uměleckých pra-instinktů (apollinského a dionýského) a jejich nivelizace. Aby tragédie, sókratovským živlem zbavena dionýských prvků, mohla nadále působit, nachází nové povzbuzující prostředky: Místo apollinského nazírání nabízí paradoxní myšlení, místo dionýského opojení afekty. ${ }^{20}$ Tak počal „teoretický člověk“, který původní Jedno rozdělil na fyzické a metafyzické, objevil tělo a duši, skutečnost a zdání, radost ze života nahradil radostí z poznání a řeckou veselost vystřídal optimismus rozumnosti. ${ }^{21} \mathrm{~V}$ tomto oddělení sídlí „věčný boj mezi světovým nazíráním teoretickým a tragickým“. ${ }^{22}$ Teoretické vykázalo umění do podoby okrasy kultury, zatímco ono je metafyzickým původem člověka i světa.

Tolik Nietzsche. Foucaultův př́iběh zrcadlí tuto figuru: Charakter vztahu rozum - nerozum má právě takovou podobu jako vztah apollinského a dionýského. Nikoli ve smyslu obrazového charakteru rozumu a opojného charakteru nerozumu, nýbrž jako dynamika této duální struktury. Svár mezi rozumem a nerozumem, vedený v jejich hutném dialogu, byl stále formou svobody šílenství (a k šílenství). Od 17. století prochází šílenství postupným přesunem v sociálním prostoru z relativně svobodného okraje (tuláci na Lodi bláznů) do uvězňujícího středu (ve „velkém uvěznění“), formují se koncepty odcizení, až nakonec dojde na podkladě morální exkluze k vědecké konceptualizaci šílenství jako duševní poruchy v „odtažitém poli objektivity“. U Nietzscheho je sókratovský živel nositelem „tragické“ disociace tragična, představující optimismus poznání. U Foucaulta je tato figura rozložitější, nicméně v principu analogická. Podobou sókratovské „humanizace“ je u Foucaulta proces „humanizace“ uvězněného šílence (tzv. „osvobození z pout v Bicêtre“ koncem 18. století), která ve skutečnosti místo osvobození přenesla vězení do „hradeb vědomí". A tak jako Nietzscheův „,teoretický člověk“ potřebuje vyvrhnout

20 Viz Nietzscheův popis sókratovského živlu v euripidovské tragédii; tamt., str. $105-109$.

21 Viz tamt., str. 127-133, k teoretickému člověku a sókratovskému optimismu.

22 Srv. tamt., str. 146: „Zde se nám vnucuje otázka, má-li síla, jíž se tragédie rozbila, i pro budoucnost dosti moci, aby zamezila uměleckému znovuzrození tragédie a tragického pohledu na svět. Byla-li tragédie ze svých kolejí vyražena dialektickým pudem k vědění a k optimismu vědy, dalo by se z toho souditi na věčný boj mezi světovým nazíráním teoretickým a tragickým; a teprve až duch vědy dospěje ke svým hranicím, jimiž bude dokázáno, že je omezen a že není universální, teprve pak by bylo lze doufati v obrození tragédie..." - Zdá se, že v této době, kdy je pro Foucaulta optimismus vědecké psychologie a psychiatrie podlomen, pro něj nastává vhodná př́iležitost, aby začal volat po obnovení tragického pojetí světa. 
afektivní stránku z myšlení (čímž vyděluje tělo a ducha, fyzické a metafyzické), tak potřebuje Foucaultův západní člověk vyvrhnout šílenství z rozumu, aby mohl být člověkem rozumným a kritickým (čímž vyděluje smysluplné a nesmyslné, jazyk a mumlání). A pokud teoretický člověk již ztrácí svůj vztah k původnímu, k „nejvnitřnějšímu základu světa“, klame kritický člověk - ve světle pravdy vědeckého rozumu - sám sebe o pravdě svého vlastního původu. „Nehybná struktura tragična“, která je konfrontována s dialektikou dějin a jíž se Foucault dovolává, je vztahem rozumu a nerozumu, který neutichá navzdory umlčení šílence. Naopak, Foucault píše:

„Vztah rozum - nerozum představuje v každém případě jednu z originálních dimenzí západní kultury; patřil k ní už dávno před Hieronymem Boschem a bude ji provázet ještě dlouho po Nietzschem a Artaudovi.“23

Foucault k nám promlouvá jako učitel věčného návratu tragického. Do záhlaví svých Dějin šilenství by mohl uvést totéž, co napsal Nietzsche v době svého posledního uzdravení a před svým definitivním zhroucením o Zrodu tragédie: „byl mým prvním přehodnocením všech hodnot.“24

Foucault nejenže následuje Nietzscheovu figuru disociace, ale staví Nietzscheovo tragično do centra své dějinné fenomenologie. ${ }^{25}$

\section{Nehybná struktura tragična}

Připomeňme zde původní předmluvu k Dějinám šilenství z roku 1961. Foucaultovo směřování zůstane nepochopené, pokud nebudeme přihlížet

23 M. Foucault, Préface, in: DE I, str. 189.

24 F. Nietzsche, Soumrak model čili: jak se filosofuje kladivem, přel. A. Breska, Olomouc 1995, str. 185.

25 Nietzscheovy dvojice apollinského a dionýského jako předobrazu vztahu rozum - nerozum u Foucaulta si všímá Dominick LaCapra ve svých přednáškách z Green College; srv. D. LaCapra, History and Reading. Tocqueville, Foucault, French Studies, Toronto 2000, str. 146 n. Viz též mírně upravená časopisecká verze ve francouzském překladu př́slušné kapitoly D. LaCapra, Relire Foucault. Relire l'Histoire de la folie, in: Revue d'histoire moderne et contemporaine, 53, 2006, str. 20 n. LaCapra však tento vztah hlouběji nerozvádí, pouze konstatuje, že u Nietzscheho je dvojice rozum - nerozum diskutována jako apollinské a dionýské. Foucaultův vztah k Nietzschemu zůstává u LaCapry pouze aluzivní. 
k tomu, že to, o co mu vlastně běží, je „nehybná struktura tragična“. Pouze ta dodává smysl i jeho následujícím slovům:

„Van Gogh a Nietzsche..., fascinováni deliriem reálného, třpytivého jevení..., jím byli rigorózně vyloučeni a znovuchyceni uvnitř utrpení bez odvolání a představovali, nejen pro druhé, leč i pro sebe..., šílenství samo. Moment Ja-sagen třpytu smyslového byl zároveň momentem jejich sestupu do stínu šílenství.

Avšak pro nás jsou tyto dva momenty rozdílné a vzdálené jako poezie a ticho, den a noc, dosažení jazyka v manifestování a jeho ztráta v nekonečnu deliria. Konfrontování nerozumu v jeho zdvojení se pro nás stalo nemožným ... Proč není možné setrvat $v$ diferenci nerozumu? Proč se nerozum pořád musí odlučovat sám od sebe, fascinován deliriem smyslového a uzavřen v ústupu do šílenství? Jak se mohlo stát, že byl nerozum připraven o jazyk v takovém rozsahu? Jaká moc petrifikovala ty, již jí vystavili svoji tvář a která je odsoudila k šilenství, když se pokusili zakusit Nerozum?“26

Tvrzení, nebo spíš obvinění, že se Foucault pokouší vyslovit „šílenství samo“, je třeba revidovat i z druhé strany. Není to šílenství, nýbrž nerozum, kdo chce promlouvat. Evokace Nietzscheho a ostatních nejsou v žádném př́ipadě prripomínkou hlasu šílenců. Foucault přece rríká: „کsílenství, to je absence díla.“27 Nehybná struktura tragična se zrcadlí právě v nerozumu, jehož formy byly zapomenuty a který zůstal pouze upomínkou v sociálně konstituovaném typu šílence.

Zatímco šílenství moderní doby je předloženo lékařskému pohledu, který určuje jeho místo v objektivitě vědění, nerozumu (nebo přesněji: ostatním formám nerozumu) je pohled upřený. Objektivizace šílenství však nepřinesla osvobození, nýbrž se stala ještě účinnějším prostředkem jeho ovládnutí než jeho předcházející „zotročení“ nerozumem.

26 M. Foucault, $H F$, str. $371 \mathrm{n}$.

27 To je teze, kterou Foucault předkládá v závěru práce. Jedna z těch, které způsobily velkou polemiku a dodnes patří k Foucaultovým nejenigmatičtějším tvrzením; srv. tamt., str. 554-557. Navzdory všemu se Foucault této teze nevzdal, což dokládá právě článek z roku 1964 Šilenství, absence dila, citovaný již výše, který se stal jedním z dodatků ke 2. vydání. Velice zajímavý výklad této teze podává J. Fulka, Foucault a literatura, in: P. Barša - J. Fulka, Michel Foucault: Politika a estetika, Praha 2005, str. 103-178. 
Navzdory tomu, že Foucault jmenuje vedle Nietzscheho i Freuda jako toho, kdo v nás objevuje místo znejist’ující všechny pravdy, přece jen o psychoanalýze tvrdí, že nedokáže rozumět hlasu nerozumu:

„Psychoanalýza může rozuzlit několik forem šílenství, zůstává ale cizincem ve svrchované práci nerozumu. Nemůže osvobodit, ani přepsat a už vůbec nemůže vysvětlit, co je v této práci esenciální.“28

Logická otázka tedy zní: Co je v Dějinách šilenství esenciální? Foucault podává následující odpověd': Od konce 18. století se „život nerozumu jako takový“" manifestuje pouze v několika dílech: v Hölderlinovi, Nervalovi, Nietzschem, Artaudovi - v dílech, která jsou díky vlastní síle rezistentní vůči vězení morálky. O několik stran dále pojmenovává jasně (když opět hovoří o de Sadeovi a Goyovi) život nerozumu jako to, v čem se mocí transgresivního aktu „znovuobjevuje možnost násilím překročit vlastní rozum a znovuobjevit tragickou zkušenost ". ${ }^{29}$

Je nepochopením, pokud se dílu vnucuje otázka, jestli je, nebo není možné navázat ztracený dialog s šílenstvím. ${ }^{30}$ Otázka, kterou si dílo vynucuje, se ptá, zda je dnes ještě možné být tragickým, aniž by byl takový člověk označen za blázna. Je dnes tragická zkušenost vůbec možná? ${ }^{31}$ Je dnes možné přivést k řeči nerozum? Mezi tragickým a šíleným je rozestup, který vyplňuje dílo. Dílo - to je vzdor tragična vůči rozpadu. Nepř́itomnost díla je zároveň opuštěním tragična, jehož fatálním důsledkem je už jen zrrícení: Nietzsche plačící v ono lednové ráno roku 1889 .

28 M. Foucault, $H F$, str. 530.

29 Tamt., str. 554; zvýraznil M. K.

30 Do tohoto kontextu bývají Dějiny šilenství zasazovány. Srv. např. J. Whitebook, Against Interiority: Foucault's Struggle with Psychoanalysis, in: G. Gutting (vyd.), The Cambridge Companion to Foucault, New York 2005, str. 323 nn. Koneckonců právě Derrida na „nemožnost jeho knihy - psát historii šílenství samého“ poukázal jako první, viz J. Derrida, Cogito a dějiny šilenství, str. 190. V návaznosti na něj tak učinili i další komentátoři (John Frow, Alan Megill aj.), jak uvádí C. Gordon, Histoire de la folie: an Unknown Book by Michel Foucault, str. 20.

31 Nelze samozřejmě tvrdit, že je to jediná otázka, kterou nám dílo samo předkládá. Je to však bezesporu dominantní otázka „,archeologie nerozumu“ jako jednoho ze syžetových plánů knihy. C. Gordon ve své snaze navázat na původní intence díla formuluje jinou otázku, která však v našem pojetí patří do jiného syžetového plánu knihy; srv. C. Gordon, Histoire de la folie: an Unknown Book by Michel Foucault, str. 23. 
Dějiny šilenství, čtené jako ,archeologie nerozumu“, prokazují, že $\mathrm{v}$ nich jde o rekonstituci tragické zkušenosti. Zatímco šílenství je ,absencí díla“, dílo samo pochází z tragické zkušenosti v diferenci nerozumu.

\section{Post scriptum $\mathrm{k}$ archeologické metodě}

Chceme-li nahlédnout, jak funguje archeologie jako metoda historického výzkumu v konkrétním provedení, nikoli v později kodifikované podobě Archeologie vědění, jejíž principy nebyly nikdy zcela uplatněny v žádném historickém zkoumání, je pokus o návrat k Dějinám šilenství, který dává přednost intenci díla před vahou jeho interpretací a především před reinterpretací samotného Foucaulta, nevyhnutelný, i když nutně metodologicky limitovaný. ${ }^{32}$ Zatím zde nedospíváme k vlastnímu popisu historické metody, ale ukazujeme její fundament: Archeologie je nietzscheovským projektem přehodnocení hodnot.

Zaměření se na „archeologii nerozumu“ a na to, co je jí vyslovováno, nám dále umožňuje nahlédnout, jak Foucault koncipuje svůj př́iběh vztahu rozumu a nerozumu symetricky $\mathrm{k}$ Nietzscheho př́iběhu ve Zrozeni tragédie, aby znovuobjevil tragickou strukturu vepsanou do zkušenosti nerozumu. Dynamika vztahu rozumu a nerozumu strukturuje historické pole, v jehož podmínkách se rodí pozitivní vědy. Archeologie je způsob, jak za scenérií poznání zahlédnout nehybnou strukturu tragična.

V myšlení archeologie vymezené jako diskursivní historie je častokrát zakryt právě ten moment, že v originální myšlence archeologie běží o zkušenost a její rekonstituci. Důvody, které Foucaulta vedly k vyhraně-

32 Naše snaha o návrat ke čtení Foucaultových Dějin šilenství není samozřjejmě ojedinělá. U příležitosti 50. výročí prvního vydání Dějin šilenství vydal francouzský Institute mémoires de l'édition contemporaine pozoruhodné dokumenty o vzniku a proměnách Foucaultova projektu Dějin šilenství od prvních náčrtů díla, nepublikovaných dokumentů i postupných edičních úprav a žádostí vydavatele o zkrácení původní verze (srv. Ph. Artières - J.-F. Bert, Un succès philosophique: L'Histoire de la folie à l'âge classique de Michel Foucault, Caen 2011) a také souhrnný pohled na dopad Foucaultova díla na intelektuální scénu a reakce i kritiky na ně v průběhu padesáti let (srv. Ph. Artières a kol., L'Histoire de la folie à l'âge classique de Michel Foucault. Regards critiques 1961-2011, Caen 2011). Nové, nezkrácené anglické vydání Foucaultova díla z roku 2006 (srv. M. Foucault, History of Madness, přel. J. Murphy - J. Khalfa, London - New York 2006) dalo samozřejmě podnět na jedné straně novým kritikám a polemikám s Foucaultovým dílem, na straně druhé i snahám o nové čtení a nové pochopení jeho místa a vlivu ve filosofii, historiografii, ale i na širší kulturní či politické scéně. 
ní archeologické metody v Archeologii vědění, je třeba zajisté studovat. Avšak při takovém studiu by nemělo zůstat nepovšimnuto, jakým způsobem se rekonstituce zkušenosti metodologicky transformuje ve Zrozeni kliniky a Slovech a věcech. ${ }^{33}$ Budoucí zkoumání by konečně měla začít se studiem hypotézy, podle které autonomie diskursu nevylučuje, nýbrž naopak metodicky umožňuje rekonstituovat zkušenosti, jež utvářely či utvářejí způsob našeho vlastního bytí, ontologii nás samých.

\section{RÉSUMÉ}

Cette étude est une interprétation de l'Histoire de la folie de Michel Foucault. Le but principal est de expliquer le sens d'une « archéologie de la déraison » comme la reconstitution de l'experiénce tragique. Il est démontré qu'une « archéologie du silence » ne signifie pas une expression de la folie elle-même, mais plutôt une tentative de révéler le silence et la déception de la raison autant que la raison cache son dialogue originel avec la déraison. Une question de tragique vient de la dyade raison-déraison, interprétée symétriquement au concept nietzschéen de l'apollinien et le dionysiaque.

33 S tím souvisí skutečnost, že samotný pojem, ,zkušenosti“ je zde epistemicky labilní. Foucault si toho byl vědom a svůj rezervovaný postoj vyjádřil již v úvodu k Archeologii vědění; srv. M. Foucault, Archeologie vědění, str. 29: „, [Archeologie vědění] přináší rovněž celou řadu oprav a vnitřní kritiky. Obecně řečeno se Dějiny šilenství věnovaly na jedné straně příliš důrazně, a na straně druhé značně enigmaticky tomu, co jsem se pokusil označit jako ,zkušenost', přičemž se ukázalo, jak málo mne tu ještě dělilo od akceptování anonymního a obecného subjektu dějin.“ To však není překážkou, aby byl pojem zkušenosti vědomě pojat do studia ,archeologické metody“, byt’ jako součást, která potřebuje patřičné osvětlení. Naopak se můžeme spíš ptát, zda je pravda, že k „metodologickému selhání archeologie“ (viz H. Dreyfus - P. Rabinow, Michel Foucault. Za hranicemi strukturalismu a hermeneutiky, přel. J. Hasala a kol., Praha 2010, str. 135 nn.) dochází v důsledku toho, že „archeologická metoda trpí několika vlastními vnitřními tenzemi“ (tamt., str. 151), nebo zda je toto selhání spíš důsledkem Foucaultovy sebeinterpretace, ve které pojem zkušenosti z popisu archeologické metody zcela vypudil. Tento problém si pochopitelně vyžaduje samostatný prostor pro studium a nemůžeme ho zde dále rozvádět. Nutno však říci, že tato studie chce být jedním ze způsobů, jak si vyklestit cestu k metodologickému uchopení archeologie. 
The paper is a reading of Michel Foucault's History of Madness. The aim is to show that the purpose of Foucault's "archaeology of unreason" is the reconstitution of tragic experience. It is shown that "an archaeology of silence" does not equal expressing madness itself; rather, it is an attempt to reveal the silence and deception of reason, insofar as reason hides its original dialogue with unreason. The second step reveals the birth of the question of the tragic in a dynamic relationship of reasonunreason, interpreted symmetrically to the Nietzschean concept of the Apollonian and the Dionysian. 